\title{
Quantitative Relationship Between Leaf Rust and Wheat Yield in Mississippi
}

\author{
M. A. Khan, Former Graduate Student, L. E. Trevathan, Professor, and J. T. Robbins, Research Assistant, De- \\ partment of Entomology and Plant Pathology, Mississippi State University, Mississippi State 39762
}

\begin{abstract}
Khan, M. A., Trevathan, L. E., and Robbins, J. T. 1997. Quantitative relationship between leaf rust and wheat yield in Mississippi. Plant Dis. 81:769-772.

Yield losses in wheat (Triticum aestivum) caused by leaf rust were evaluated in cultivar trials at five locations in Mississippi over a 4-year period from 1986 through 1989. Different levels of disease developed in the various trials over the 4 -year period. There was no significant interaction between location and cultivar when yield data were collected from sites in the north and central areas of the state. A model derived from data for eight cultivars at two locations showed a negative linear relationship between yield and leaf rust. Total grain yield was reduced by $1 \%$ for each $1 \%$ increase in rust when the percentage flag leaf area covered by pustules was assessed visually at Feekes stage 11.1. Using this model, and rust ratings from three additional locations, predicted yields were statistically similar to recorded yields.
\end{abstract}

The southeastern United States is a distinct agroecological area of adaptation based on geographic and environmental similarities. Wheat production in this area is dedicated primarily to southern-adapted soft red winter wheats. Epidemics of leaf rust occur on soft red winter wheat in the southeastern United States $(20,25,28)$ because wheat cultivars adapted to environmental conditions in the area lack durable resistance to the leaf rust fungus. This is primarily due to diverse virulences of $P u c$ cinia recondita Roberge ex Desmaz. f. sp. tritici and local overwintering or oversummering of inoculum $(17,26)$. Studies conducted from 1978 to 1985 on the virulence of races of this pathogen identified the southern United States as a region of distinct epidemiological units $(19,21,22)$. The effect of specific environmental conditions on leaf rust development has been studied $(7,9-12,14,28,29)$. Wheat leaf rust development in response to local climatic conditions has also been reported for selected locations $(13,27)$.

Bowen et al. (6) identified a linear relationship between maximum wheat yield and area under the disease progress curve when powdery mildew and leaf rust were major contributors to overall disease. Their results were based on data from one season at two locations in North Carolina. Buchenau (8) previously described a me-

Corresponding author: L. E. Trevathan

E-mail: 1trevathan@plantpath.msstate.edu

Published with approval of the Director of the Mississippi Agricultural and Forestry Experiment Station as paper $\mathrm{J}-9070$

Accepted for publication 25 March 1997.

Publication no. D-1997-0519-04R

(C) 1997 The American Phytopathological Society thod of rust loss prediction in which the relationship between percent yield loss and area under the rust progress curve was 1 to 1 .

Characterization of leaf rust development and yield response of wheat in Mississippi could help describe effects of leaf rust epidemics in the Southeast. Long et al. (20) described leaf rust epidemiological zones east of the Mississippi River as smaller than currently defined agroecological zones. The primary objective of this study was to characterize the relationship between leaf rust and yield based on 4 years of data obtained from wheat cultivar trials conducted at selected locations in central and northern Mississippi (1-4). Leaf rust severity and yield data were then used to develop a model of the relationship between yield and disease. This relationship was validated to determine if the effect of disease on yield was similar for cultivars grown in the central and northern areas of the state.

\section{MATERIALS AND METHODS}

The wheat cultivars Bradford, Coker 916, Florida 302, Massey, Pioneer 2550, Pioneer 2551, Tyler, and Williams were grown on the Mississippi Agricultural and Forestry Experiment Station (MAFES) Plant Science Research Farm at Starkville and on branch research stations in Mississippi from 1986 to 1989. The Holly Springs location is $198 \mathrm{~km}$ north of Starkville; Pontotoc is $120 \mathrm{~km}$ northwest; Stoneville is $222 \mathrm{~km}$ west, next to the Mississippi River; and Brooksville is 45 $\mathrm{km}$ southeast of Starkville. At each location, plots consisted of eight rows $6 \mathrm{~m}$ long and spaced $18 \mathrm{~cm}$ apart, arranged in a randomized complete block design of four blocks per plot. Plots were limed and fertilized with $\mathrm{P}_{2} \mathrm{O}_{5}$ and $\mathrm{K}_{2} \mathrm{O}$ according to soil test recommendations of the Mississippi Cooperative Extension Service. All seeds were packaged for planting at the rate of 65 seeds per meter of row. Plots were planted with a cone, spinner-divider planter. Nitrogen was applied at the rate of $32 \mathrm{~kg} / \mathrm{ha}$ at planting and $90 \mathrm{~kg} / \mathrm{ha}$ in late February. Natural inoculum was relied upon for infection at each location. Foliar fungicides were not applied to ensure that ratings were made under naturally existing conditions of disease pressure. Herbicides were applied at each location as needed for broadleaf and grass weed control (1-4).

Wheat cultivars were rated for leaf rust development according to James' Manual of Assessment Keys for Plant Diseases (15). At Feekes growth stage 11.1 (milky ripe), 10 plants of each cultivar were selected at random from each plot at Starkville and Holly Springs. Leaf rust severity (the percentage of the total flag leaf surface affected by rust) was recorded; the maximum percentage of area affected by leaf rust according to James' Manual is $25 \%$. An assessment was also made of the overall disease response of each cultivar. Very low incidence of powdery mildew and/or Septoria leaf blotch occurred on a few cultivars; however, the predominant disease over all locations and years was leaf rust (1-4).

For each year at each location, plots were established in a randomized complete block with cultivars considered as treatments. Data were combined over years and locations, and location was treated as a fixed effect to determine how cultivars affected yield and disease. The experimental design for data combined over years was a split plot with location as the main unit, year as replication, and cultivar as the subunit. Main effects of interest were cultivar and the cultivar by location interaction; data were averaged over replications within years to simplify the analysis.

Environmental data were obtained from nearby weather stations at each location. Daily ambient air temperature and total rainfall were recorded from September through May each year. Weather data were then averaged to determine the synoptic meteorology at each location.

Yield was measured in cultivar trials from 1986 to 1989 and regressed on rust severity. Linear regression models were developed to predict yield as a function of disease based on data from the Starkville and Holly Springs locations. The best-fit model was determined by $F$ statistics, and coefficients of determination $\left(r^{2}\right)$ estimated the proportion of the variation in yield 
explained by leaf rust. Data from cultivars Massey, Pioneer 2550, and Pioneer 2551 grown at the Brooksville, Pontotoc, and Stoneville locations were used to validate the model.

\section{RESULTS}

Leaf rust severity and yield were significantly different between cultivars at the two locations during the 4-year period (Table 1). There was no interaction between location and cultivar for leaf rust or yield. Leaf rust severity was significantly higher on Massey, which produced 3012 $\mathrm{kg} / \mathrm{ha}$, compared to all other cultivars (Table 2). Rust severity on Williams, Tyler, and Pioneer 2550 was not statistically different; Tyler, Pioneer 2550, and Coker 916 had similar severity ratings; and Pioneer 2550, Coker 916, Pioneer 2551, Bradford, and Florida 302 rust ratings were not statistically different. Florida 302 had the lowest disease severity rating, and a yield of $3682 \mathrm{~kg} / \mathrm{ha}$, over 4 years at the two locations.

Environmental conditions. Maximum air temperature was higher at Starkville than at Holly Springs, and in 1986 and 1988 these differences were statistically significant. Minimum temperatures were always lower at Holly Springs; in 1986, 1987, and 1988 these temperatures differed significantly. As a result, average ambient air temperatures were significantly lower at Holly Springs than at Starkville during the same three years, and the difference was about $2^{\circ} \mathrm{C}$. $\mathrm{Cu}-$ mulative rainfall was not different between the two locations.

Model development. A model derived from data for eight cultivars over 4 years at Starkville and Holly Springs showed a negative linear relationship between yield and leaf rust (Fig. 1). Rust severity meas-

Table 1. Analysis of variance for effects of location and cultivar on yield and leaf rust for eight wheat cultivars grown at Starkville and Holly Springs, Mississippi, 1986 to 1989

\begin{tabular}{lrrrc}
\hline Variable & Source of variation & df & MSE & $\boldsymbol{P}>\boldsymbol{F}$ \\
\hline Leaf rust & Year (Yr) & 3 & 279.03 & $\ldots$ \\
& Location (L) & 1 & 44.43 & $\ldots$ \\
& Yr $\times$ L & 3 & 31.69 & $\ldots$ \\
& Cultivar (C) & 7 & 381.56 & $0.001^{\text {a }}$ \\
& L $\times$ C & 7 & 18.48 & 0.850 \\
Erro & 30 & & \\
Yield & Year (Yr) & 3 & $2,351.51$ & $\ldots$ \\
& Location (L) & 1 & 16.91 & $\ldots$ \\
& Yr $\times$ L & 3 & 994.12 & $\ldots$ \\
& Cultivar (C) & 7 & 117.30 & $0.033^{\text {b }}$ \\
& L $\times$ C & 7 & 51.42 & 0.369 \\
& Error & 30 & & \\
\hline
\end{tabular}

a Significantly different at $P \leq 0.01$.

${ }^{\text {b }}$ Significantly different at $P \leq 0.05$.

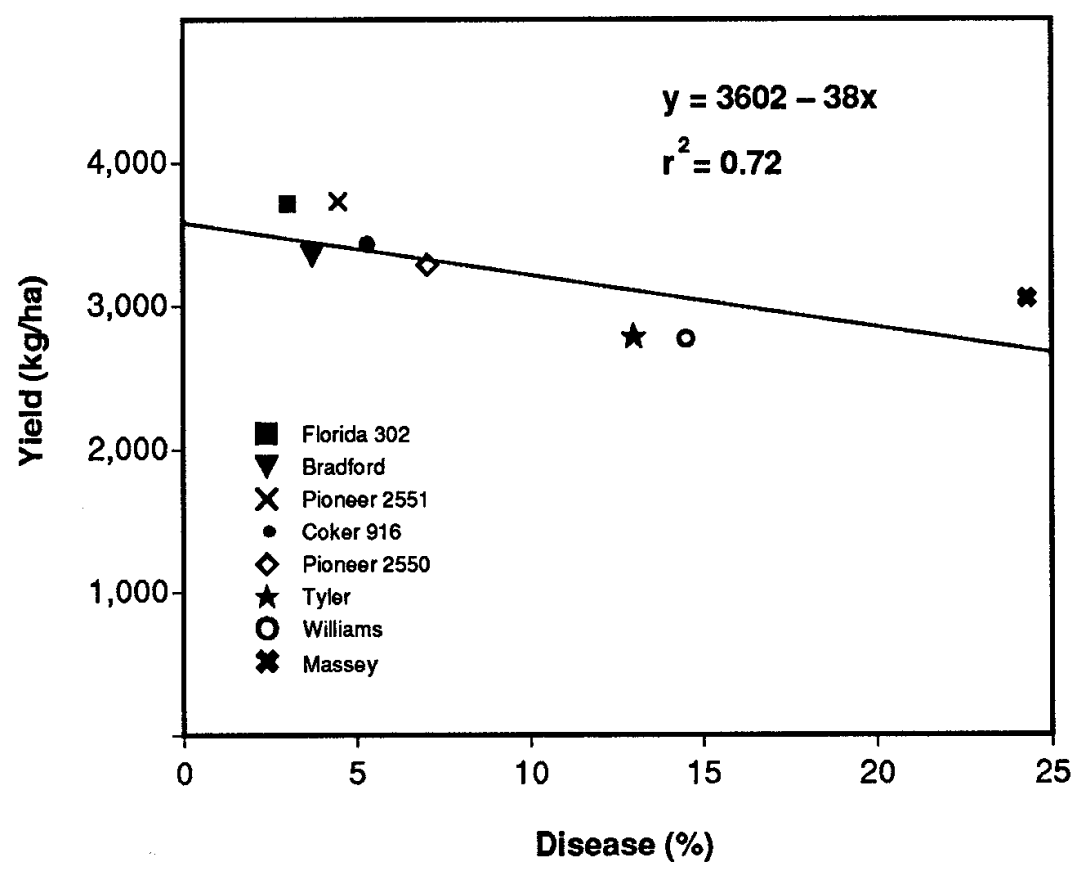

Fig. 1. Regression of wheat yield on leaf rust severity at Feekes stage 11.1 for eight cultivars grown in northern and central Mississippi, 1986 to 1989. ured at the milky ripe growth stage (Feekes 11.1) explained a substantial part of the variation in yield. For each $1 \%$ increase in flag leaf area covered by pustules (assessed visually at Feekes 11.1), yield was reduced by $1 \%$.

Model validation. The model developed from the data described above was used to predict yield at Pontotoc, Brooksville, and Stoneville. Yield data from these three locations during 1986 to 1989 were used for validation. Based on analysis of variance, there were significant differences in disease severity and yield at the three locations; there were no significant interactions between location and cultivar (Table 3). Observed and predicted values for yield were in agreement for the three cultivars, based on the model $y=3602-38 x$, where $x=$ rust severity at Feekes 11.1 and $y=$ yield in $\mathrm{kg} / \mathrm{ha}$ (Table 4).

\section{DISCUSSION}

Since occurrence of new races of the leaf rust fungus is routinely monitored (1722) and only a limited number of new wheat cultivars are released each year, we reasoned that potential yield reduction in available cultivars caused by prevalent rust races would be useful in disease management decisions. Previous studies of the relationship between yield loss and disease development that reported results similar to those described here were based on combined infections by the stem rust and leaf rust fungi $(8,23)$. Single infections by the stem rust fungus caused greater yield reduction than combined infections of the two fungi $(16,23)$. In combined infections, effects on the host were dominated by the leaf rust fungus.

Responses to the leaf rust fungus $P$. recondita f. sp. tritici were cultivar-dependent in our study. Pioneer 2550, Coker 916, Pioneer 2551, Bradford, and Florida 302 had flag leaf infections of less than $10 \%$. Tyler and Williams had infection percentages between 10 and $15 \%$, and Massey had greater than $20 \%$. Because of the fre-

Table 2. Mean leaf rust and yield of eight cultivars grown at two locations in Mississippi, 1986 to 1989

\begin{tabular}{lcl}
\hline Variety & $\begin{array}{c}\text { Leaf rust } \\
(\%)\end{array}$ & $\begin{array}{c}\text { Yield } \\
(\mathbf{k g} / \mathbf{h a})\end{array}$ \\
\hline Massey & $24.3 \mathrm{a}$ & $3,012 \mathrm{bc}$ \\
Williams & $14.5 \mathrm{~b}$ & $2,740 \mathrm{c}$ \\
Tyler & $13.0 \mathrm{bc}$ & $2,792 \mathrm{c}$ \\
Pioneer 2550 & $7.0 \mathrm{bcd}$ & $3,280 \mathrm{abc}$ \\
Coker 916 & $5.3 \mathrm{~cd}$ & $3,418 \mathrm{ab}$ \\
Pioneer 2551 & $4.6 \mathrm{~d}$ & $3,698 \mathrm{a}$ \\
Bradford & $3.8 \mathrm{~d}$ & $3,378 \mathrm{ab}$ \\
Florida 302 & $3.1 \mathrm{~d}$ & $3,682 \mathrm{a}$ \\
\hline
\end{tabular}

a Data represent means of leaf rust and yield from Starkville and Holly Springs. Means within a column followed by the same letter are not different according to least significant difference $(P \leq 0.05)$ calculated by procedures from SAS Release 6.03. 
quency of development of new cultivars and the distribution of rust races east of the Mississippi River (21), cultivar reaction to the leaf rust fungus is likely to result in a range of disease severity ratings from low to high.

In Mississippi, wheat cultivars are classified as resistant (R), moderately resistant (MR), moderately susceptible (MS), or susceptible (S) based on the variation among commercially available and public cultivars entered in the statewide Variety Testing Program (5). This designation is useful to producers because it identifies the potential of certain cultivars to develop significant disease. However, the designation does not account for the presence or absence of other agronomic characteristics nor practical considerations such as seed availability. If producers choose cultivars with designations of MS or S, it may be necessary for them to utilize additional disease management strategies.

The general linear model, $y=3602-$ $38 x$, estimated the effect of rust on wheat yield in central and northern Mississippi over a 4-year period. This equation, generated from data over multiple growing seasons and several locations, accurately predicted wheat yield for this region of the state. For soft red winter wheat cultivars commonly grown in Mississippi, $1 \%$ of the flag leaf covered by rust pustules resulted in a $1 \%$ yield reduction for disease severities up to approximately $20 \%$. Cultivars with less than $10 \%$ rust, including Bradford, Coker 916, Florida 302, Pioneer 2550, and Pioneer 2551, had yields of 3280 to $3698 \mathrm{~kg} / \mathrm{ha}$. Florida 302, which had the lowest leaf rust rating, yielded $3682 \mathrm{~kg} / \mathrm{ha}$. Massey, Tyler, and Williams, which had more than $10 \%$ rust, yielded 3012, 2792, and $2740 \mathrm{~kg} / \mathrm{ha}$, respectively. Based on data compiled by the USDA-ARS Cereal Rust Laboratory in St. Paul, Minnesota, a statewide average of $1 \%$ leaf rust in Mississippi in 1996 resulted in the loss of over 3 million $\mathrm{kg}$ of wheat (D. L. Long, personal communication).

The use of damage functions has been proposed to improve disease management decisions for corn affected by common rust (24). Based on results of our study, leaf rust damage functions for wheat produced in the southeastern United States could be used effectively in pest management decisions. When leaf rust severity approaches levels that result in economically significant yield reductions, fungicides could be used. This also provides a basis for the use of resistance in commercial cultivars. To be useful in this area of the United States, cultivars must be sufficiently resistant to ensure that the flag leaf area affected by leaf rust does not result in yield losses considered economically unacceptable by producers.

For determination of the quantitative relationship between wheat yield and leaf rust, the northern and central portions of Mississippi can be considered to be within the same epidemiological zone. This was true even though minimum and average ambient temperatures were significantly different during three of the four years of the study. Apparently, differences of $2^{\circ} \mathrm{C}$ in temperature do not distinguish separate epidemiological units of this disease. Based on the disease severity on and yield of eight cultivars over 4 years in central and northern Mississippi, management decisions which result in reduced disease development on wheat flag leaves provide higher yields.

Table 3. Analysis of variance for effects of location and cultivar on yield and leaf rust for three wheat cultivars grown at Pontotoc, Stoneville, and Brooksville, Mississippi, 1986 to 1989

\begin{tabular}{lcrrr}
\hline Variable & Sources of variation & df & MSE & $\boldsymbol{P}>\boldsymbol{F}$ \\
\hline Leaf rust & Year (Yr) & 3 & 66.93 & $\ldots$ \\
& Location (L) & 2 & 98.08 & $\ldots$ \\
& Yr $\times$ L & 5 & 124.88 & $\ldots$ \\
& Cultivar (C) & 2 & 769.88 & $0.001^{\text {a }}$ \\
& L $\times$ C & 4 & 59.83 & 0.408 \\
Error & 32 & & \\
Yield & Year (Yr) & 3 & 1908.42 & $\ldots$ \\
& Location (L) & 2 & 327.83 & $\ldots$ \\
& Yr $\times$ L & 5 & 46.63 & $\ldots$ \\
& Cultivar (C) & 2 & 500.46 & $0.005^{\text {a }}$ \\
& L $\times$ C & 4 & 18.75 & 0.882 \\
& Error & 32 & & \\
\hline
\end{tabular}

${ }^{\text {a }}$ Significantly different at $P \leq 0.01$.

Table 4. Observed and predicted yields for three wheat cultivars grown at three locations in Mississippi, 1986 to 1989

\begin{tabular}{lccc}
\hline Variety & Observed yield $(\mathbf{k g} / \mathbf{h a})$ & Predicted yield $(\mathbf{k g} / \mathbf{h a})$ & LSD \\
\hline Massey & $2,864^{\mathrm{a}}$ & 2,951 & $1,008 \mathrm{NS}^{\mathrm{b}}$ \\
Pioneer 2550 & 3,476 & 3,644 & $807 \mathrm{NS}$ \\
Pioneer 2551 & 3,731 & 3,623 & $652 \mathrm{NS}$ \\
\hline
\end{tabular}

${ }^{a}$ Data represent mean yield for these cultivars grown at Pontotoc, Stoneville, and Brooksville.

${ }^{\mathrm{b}}$ Not significant.

ACKNOWLEDGMENTS

We thank D. L. Boykin, Area Statistician, USDA-ARS Mid-South Area, Stoneville, MS for statistical advice.

\section{LITERATURE CITED}

1. Askew, J. E., Jr. 1986. Wheat variety trials. Miss. Agric. For. Exp. Stn. Info. Bull. 92.

2. Askew, J. E., Jr. 1987. Wheat variety trials. Miss. Agric. For. Exp. Stn. Info. Bull. 109.

3. Askew, J. E., Baugh, E., Boykin, F., Edwards, N., Elmore, R., Fisher, C., Hovermale, C., Johnson, B., Reginelli, D., Sanders, T., Stevens, G., and Vaughan, T. R. 1988. Wheat variety trials. MAFES Info. Bull. 129.

4. Askew, J. E., Baugh, E., Boykin, F., Edwards, N., Fisher, C., Hovermale, C., Ivy, R., Johnson, B., Johnson, J., Reginelli, D., Trevathan, L., and Vaughan, T. R. 1989. Wheat variety trials. MAFES Info. Bull. 146.

5. Askew, J. E., Baugh, E., Boykin, F., Foster, T., Hovermale, C., Ingram, D., Johnson, B., Main, J., Saunders, R., Trevathan, L., and Vaughan, T. R. 1993. Wheat and oat variety trials. MAFES Info. Bull. 248.

6. Bowen, K. L., Everts, K. L., and Leath, S. 1991. Reduction in yield of winter wheat in North Carolina due to powdery mildew and leaf rust. Phytopathology 81:503-511.

7. Browder, L. E., and Eversmeyer, M. G. 1987. Influence of temperature on development of Puccinia recondita with Triticum aestivum 'Suwon 85.' Phytopathology 77:423-425.

8. Buchenau, G. W. 1975. Relationship between yield loss and area under the wheat stem rust and leaf rust progress curves. Phytopathology 65:1317-1318.

9. Chester, K. S. 1943. The decisive influence of late winter weather on wheat leaf rust epiphytotics. Plant Dis. Rep. Suppl. 143:133144.

10. Eversmeyer, M. G., and Burleigh, J. R. 1968. Effect of temperature on the longevity of Puccinia recondita f. sp. tritici urediospores on dry wheat foliage. Plant Dis. Rep. 52:186188.

11. Eversmeyer, M. G., Kramer, C. L., and Browder, L. E. 1980. Effect of temperature and host:parasite combination on the latent period of Puccinia recondita in seedling wheat plants. Phytopathology 70:938-941.

12. Eyal, Z., and Peterson, J. L. 1967. Uredospore production of five races of Puccinia recondita Rob. ex. Desm. tritici as affected by light and temperature. Can. J. Bot. 45:537-540.

13. Fogliani, G., and Caffarri, E. 1986. Experimental researches in Otrepo Pavese (Padana Velly), on wheat rust epidemiological aspects related to the climatic conditions. J. Phytopathology 115:2-20.

14. Hassan, Z. M., Kramer, C. L., and Eversmeyer, M. G. 1986. Summer and winter survival of Puccinia recondita and infection by soilborne urediniospores. Trans. Br. Mycol. Soc. 86:365-372.

15. James, C. 1971. A Manual of Assessment Keys for Plant Disease. Can. Dept. Agric. Pub. No. 1458.

16. Kingsolver, C. H., Schmitt, C. G., Peet, C. E., and Bromfield, K. R. 1959. Epidemiology of stem rust: II. (Relation of quantity of inoculum and growth stage of wheat and rye at infection to yield reduction by stem rust). Plant Dis. Rep. 43:855-862.

17. Kolmer, J. A. 1992. Diversity of virulence phenotypes and effect of host sampling between and within populations of Puccinia recondita f. sp. tritici in Canada. Plant Dis. 76:618-621.

18. Leonard, K. J., Roelfs, A. P., and Long, D. L. 1992. Diversity of virulence within and among populations of Puccinia recondita $\mathrm{f}$. sp. tritici in different areas of the United 
States. Plant Dis. 76:500-504.

19. Long, D. L., Roelfs, A. P., Leonard, K. J., and Roberts, J. J. 1993. Virulence and diversity of Puccinia recondita $\mathrm{f}$. sp. tritici in the United States in 1991. Plant Dis. 77:786-791.

20. Long, D. L., Schafer, J. F., and Roelfs, A. P. 1985. Specific virulence of Puccinia recondita f. sp. tritici in the United States from 1978 through 1983. Plant Dis. 69:343-347.

21. Long, D. L., Schafer J. F., and Roelfs, A. P. 1986. Virulence and epidemiology of Puccinia recondita f. sp. tritici in the United States in 1984. Plant Dis. 70:395-397.

22. Long, D. L., Schafer, J. F., Roelfs, A. P., and Roberts, J. J. 1986. Virulence and epidemiology of Puccinia recondita f. sp. tritici in the
United States in 1985. Plant Dis. 70:11071110 .

23. McGrath, M. T., and Pennypacker, S. P. 1991. Reduction in the rate and duration of grain growth in wheat due to stem rust and leaf rust. Phytopathology 81:778-787.

24. Pataky, J. K. 1987. Quantitative relationships between sweet corn yield and common rust, Puccinia sorghi. Phytopathology 77:10661071.

25. Roelfs, A. P. 1986. Development and impact of regional cereal rust epidemics. Pages 129150 in: Plant Disease Epidemiology, Vol. 1, Population Dynamics and Management. K. J. Leonard and W. E. Fry, eds. Macmillan Publishing Company, New York.

26. Roelfs, A. P. 1991. Epidemiology of the cereal rusts in North America. Can. J. Plant Pathol. 11:86-90.

27. Sahni, M. L., and Prasada, R. 1963. A study of the environmental conditions influencing the development of the three rusts of wheat in the neighborhood of Delhi. Indian Phytopathol. 14:285-300.

28. Subba Rao, K. V., Berggren, G. T., and Snow, J. P. 1990. Characterization of wheat leaf rust epidemics in Louisiana. Phytopathology 80:402-410.

29. Tomerlin, J. R., Eversmeyer, M. G., Kramer, C. L., and Browder, L. E. 1983. Temperature and host effects on latent and infectious periods and on urediniospore production of Puccinia recondita f. sp. tritici. Phytopathology 73:414-419. 